\title{
Fostering Democratic Intelligence of Young Citizens Through the Implementation of Civic Education Classroom as Democratic Laboratory
}

\author{
D. Sundawa \\ Departement of Civic Education, Universitas Pendidikan Indonesia \\ Bandung, INDONESIA \\ d_sundawa@yahoo.com
}

\begin{abstract}
Nowadays, young citizens often misunderstand the meaning of democracy, interpreting it as an unlimited freedom, which in turn leads to anarchical acts. This situation is inseparable from the ineffective embodiment of democratic values in civic education classroom in particular. For this reason, the purpose of this study was to investigate several factors that can foster democratic intelligence of students in the classroom in Indonesia. These factors, including Civic Education Teacher Competence, School Environmental Factor, and Civic Education Class, and Democratic Intelligence of Young Citizens as Students, were studied. To clarify the effect of several factors, mixed quantitative and qualitative approaches were chosen to gather data from civic education teachers participating in Teacher Certification Program, organized by Universitas Pendidikan Indonesia, as well as from the Committee and teachers from the City of Sukabumi and Purwakarta and Garut Regencies. The findings showed that to create civic education classroom as a Democratic Laboratory, development of a conducive school environmental factor and school leadership adopting SchoolBased Management principles was important. This development will lead effective implementation of democracy in realistic social life, especially in Indonesia as a mixed-culture country.
\end{abstract}

Keywords-Democracy, Citizen, Democratic Laboratory, and Civic Education

\section{INTRODUCTION}

Since the era of reformation in 1998, democracy, as one of the media for freedom, has penetrated various aspects of life in Indonesia, including education. However, in its implementation, democracy has frequently been misunderstood as an unlimited freedom. The main reason for the ineffective implementation of democracy is due to the unsuccessful cultivation of democratic value in education, specifically in the civic education. Certainly, this unsuccessful education creates citizens' immaturity and tactlessness in applying democracy in realistic life. Further, the subject in education has been just an indoctrination room that murders brevity, freedom and creativity of citizens, who are potential to have the ability to practice democracy intelligently to solve various problems honestly and justly, both for themselves and others. In turn, problems in the miniature of a society reflecting the social and cultural realities can be created, such as having the courage to ask, giving opinion, arguing, tolerating, learning to appreciate and respect other's opinion, taking responsibility, and being honest and fair both with other citizens, between citizens and teachers, and between citizens and the teaching materials.

[1] stated that some educationalists concerned with education for democracy, however, have never been convinced that simply informing students about their government through doses of formal civic education was sufficient. One of the attempts to foster democratic intelligence of students is through developing an effective civic education. This education is important for informing definition and application of democracy in the realistic social life. However, delivering the knowledge of democracy should be followed by the way of teaching. Therefore, to be successful in teaching, elimination of an indoctrination room during teaching should be the best choice.

[2] stated that civic Education will be more meaningful if functional knowledge and social problems enrich the basic concepts of Civic Education, and creative dialogues in instruction are developed. Therefore, the fostering democracy is not based on individual or group's will or interest, nor it is based on the belief of unlimited freedom; instead, it is based on responsible democracy on the basis of the noble values of national culture, namely Pancasila (The Five Principles of Indonesia).

Beside Somantri, the idea of classroom as democratic laboratory was initially put forward by John Dewey. A neopragmatic interpretation of Dewey' $\mathrm{s}$ work creates new visions for the relationship between democracy and education. The idea of deliberative democracy as an educational process offers an image of a kind of communication where different perspectives are brought into ongoing meaning creating processes of will-formation [3]. An exploration of how Dewey's principles of equality, intelligent judgment and action, and working together reveal an overlapping theme of student voice, a theme which was further explored by examining lessons learned through the use of these principles in the classroom. Teachers implementing a democratic pedagogy not only seek classrooms of open dialogue, they also encourage critical student feedback on traditional aspects of school [4]. Students grapple with higher-order questions 
around the need for collaboration and the meaning of personal mastery and are required to apply such skills to real-life work as well as their understanding of why it is important to them and their world [5].

Definition of democracy was also stated by Ki Hajar Dewantoro. In the mind of Ki Hajar Dewantoro, the spirit of education is "ing ngarso tsung tulodo" (giving example from the front), "ing madya mangun karsa" (building up spirit from the middle) and "tut wuri handayani" (supervising from the back). It is further stated that a good teacher is one who is willing to see and absorb students' feelings, has high understanding of the feelings, believes that his/her students have the abilities, able to serve as facilitator (provider of ease, success), and able to play the role of an inquiring teacher. Based on above definition of democracy, many researchers are then following and studying further applications of democracy, as well as learning how to deliver this democracy to people and citizen. [6] reported that $70 \%$ of the respondents believe that teaching methods are authoritarian as taught by the teacher, the students learn, and the principal is considered the all powerful commander while the school system tends to be a bank from where students come and take knowledge. [7] stated that the way democracy is thought and lived in this classroom seems to hold great potential for promoting knowledge in and about democracy. However, freedom of expression is democratic only on the grounds of an equal playing field [8]. [9] believe that the teachers' action or acceptance of the students' participation in class decisions may have been born out of the wisdom that if they did not, students might not comply with the rules and regulations, thus aggravating behavior problems in class. But, career education programs undermine democratic learning in a variety of ways [10]. [11] stated that we have also suggested numerous approaches that would allow career education to achieve its full democratic potential by allowing students and workers to influence labor-market, economic, and social conditions. [12] therefore the education system should prepare the youth for robust involvement in the democratic process

In fact, this information is important for Civic Education teachers to be willing and able to develop their selfcompetences through various media and professional platforms such as teacher's association of subject matter, teacher certification, and other various academic forums. This is the principle of democratic education that should be made as a role model for the Civic Education classroom instruction in schools.

All instruments in democratic instruction, such as teachers, subject content, instructional media, learning resources, assessment system, and instructional infrastructure should be well-prepared in order to reflect a democratic life, both in the classroom and school, so that school and Civic Education classroom as democratic laboratory can be created. Based on the above explanations, a question emerges, namely "How to foster democratic intelligence of citizens through the implementation of Civic Education classroom as democratic laboratory?"
Here, the purpose of this study was to investigate several factors that can foster democratic intelligence of students in the classroom in Indonesia. These factors, including Civic Education Teacher Competence, School Environmental Factor, and Civic Education Class, and Democratic Intelligence of Young Citizens as Students, were studied. To clarify the effect of several factors, mixed quantitative and qualitative approaches were chosen to gather data from civic education teachers participating in Teacher Certification Program, organized by Universitas Pendidikan Indonesia, as well as from the Committee and teachers from the City of Sukabumi and Purwakarta and Garut Regencies.

\section{METHODOLOGY}

Mixed quantitative and qualitative approaches with the dominant-less-dominant design [13] was chosen for the research to gather data from Civic Education teachers participating in the certification program held by Universitas Pendidikan Indonesia in Area 10, added with 202 teachers from schools in Sukabumi City, Purwakarta and Garut Regencies, and also 673 students, consisting of 376 junior secondary school and 277 senior secondary school students.

The quantitative approach was aimed to reveal the correlation between the variables of teacher competence and school environmental factor with Civic Education classroom serving as democratic laboratory in an attempt of fostering democratic intelligence of young citizens. In this quantitative research, attempts were made to analyze the significances of correlation between the above variables, degree of contribution of the variables, and results of correlational test. Therefore, it tested the magnitude of the relationship between and linearity of the variables. Meanwhile, qualitative approach was employed to gain in-depth understanding of the data obtained through quantitative approach.

The research instruments were developed based on democratic instructional theory. The one used to measure the variable of Civic Education Teacher Competence (X1); School Environmental Factor (X2); Class as Democratic Laboratory (Y), and Democratic Intelligence (Z) was SSHAscaled questionnaire (Survey of Study Habits and Attitudes) by Brown and Holtzman, previously adjusted to Indonesian cultural environment, with the following scales: 5 = Strongly Agree; 4 = Agree; 3 = Neutral; 2 = Disagree; and $1=$ Strongly Disagree.

In implementing the whole dimensions of the approaches, data collection techniques consisted of questionnaire distribution, observation, in-depth interview, focus group discussion, and documentary study. Meanwhile, the sources of information included literature; Civic Education teachers; students of junior, senior, and vocational secondary schools in Bandung, Sukabumi, Cirebon, Indramayu, Purwakarta, Majalengka, Sumedang, and Garut; and principals. 


\section{RESULTS AND DISCUSSION}

A. The Influence of Civic Education Teacher Competence, School Environmental Factor, and Civic Education Class as Democratic Laboratory on Democratic Intelligence of Young Citizens as Students

In general, the gained score for each variable was relatively evenly distributed. The variable of Civic Education teacher competence (X1) had a higher average compared to other independent variables, namely school environmental factor (X2) and class as democratic laboratory (X3). The high score the $\mathrm{X} 1$ variable gained did not necessarily mean that the variable had a high influence on the variable of students' democratic intelligence compared to other independent variables.

Data analysis showed that the coefficient correlation for the variables of Civic Education teacher competence and students' democratic intelligence was 0.552 . On the other hand, the correlation between the variables of school environmental factor and students' democratic intelligence was 0.515 , and the correlation between the variables of class as democratic laboratory and students' democratic intelligence was 0.683 . Theoretically, because the coefficient correlation between class as democratic laboratory and students' democratic intelligence was high, then the variable of class as democratic laboratory had a higher influence on the variable of students' democratic intelligence than the variables of Civic Education teacher competence and school environmental factor.

The indicators contributing greatly to teacher competence are:

a. Assessing students fairly;

b. Making wise/impartial decision;

c. Not being authoritarian in democratic classroom;

d. Providing students with opportunities to exchange ideas;

e. Correcting various students' comments inappropriate to the topic being discussed in the classroom;

f. Giving follow-up plan after instruction for the next meeting, so that students will have materials to study.

The above views of education reveal that the recent definition of teaching and learning has already been highly student-centred, where teachers only play the role of planning to give students opportunities to develop the learning activity and explore various new experiences to reach various idealized competences; and this role distribution has been a consensus between students and the teacher [14].

Meanwhile, the indicators contributing greatly to students' democratic intelligence are:

a. Social interaction is needed in instructional process;

b. Students open social interaction with others;

c. Students' spiritual intelligence will be a noble personality;

d. Upholding human rights is a good example; e. High motivation strongly encourages students' success;

f. Self-confidence is important for students;

g. Students have the ability to think creatively; and

h. Students have healthy body and mind.

Nevertheless, the data demonstrated that environmental factor had a very low contribution on the effort of fostering students' democratic intelligence, whereas according to [15], a number of indicators of the implementation of school or class as democratic laboratory are: School as socio-pedagogic institution; school as a medium of cultivation and empowerment; school as an integrated entity managed systematically with school-based management paradigm; school as micro cosmos of democracy; and school as a site of democratic city.

On the other hand, the significance level of one side correlation coefficient of the output (measured from probability) resulted in 0.000 or practically 0 . Thus, the probability was far below 0.05 , so that the correlation between the variables of teacher competence, school environmental factor, and civic education classroom as democratic laboratory and the variable of students' democratic intelligence was obviously high.

The new education paradigm demands that education be able to produce democratic human beings who will play their own roles as parts of the nation in the social and state lives. What education contributes to democracy is preparing the citizens to think critically and act democratically, namely ensuring citizens' rights, conducting instructional process, and transforming democratic values. Democratic administration of school, as an attempt of catching up with other Asian countries (Malaysia, Singapore, Japan) in the field of education, involves the society, school committee, and school council as well as stakeholders [16].

[17] stated that for achieving democracy; sacrifice, courage, vision, symbolism, and participation are the critical characteristics of democratic.

\section{B. The Influence of Civic Education Teacher Competence on the Implementation of Civic Education Class as Democratic Laboratory}

To understand more about other factor that influence the implementation of civic education, competence of civic education teacher was also examined. We found that a correlation value of 0.713 was gained with a significance level of $50.84 \%$. This result means that civic education teacher competence has a high significance on the implementation of civic education class as democratic laboratory.

The impact of this pedagogic mastery is that teachers will master learning theories and pedagogic instructional principles, be able to develop curriculum pertaining to the subject they teach, administer nurturing instruction, as well as utilize information and communication technology for instructional interest, and facilitate the actualization of students' potential development. Hence, teachers will be able to communicate effectively, empirically, and politely with the students. 
Civic education instructional process in the classroom will be far more interesting for students if teachers master professional competence. By mastering this competence, they will be able to master the content, structure, concept, and pedagogic patterns that support the subject they teach, and develop instructional material creatively, as well as take advantage of information and communication technology. [18] stated that for citizenship education seems to emphasize either community based involvement or classroom based cognitive reflection.

[19] reported that for higher education and careers, the school benefited them by allowing them to develop their own interests and by fostering such traits as personal responsibility, initiative, curiosity, ability to communicate well with people regardless of status, and continued appreciation and practice of democratic values. Ginn (1996: 356) reported that research on education and democratization clearly demonstrates that democratic engagement in adult life is the result of having participated as a youth. Cognitive know-ledge and attitudes do not predict later participation, but student participation in adult political activities does. In other words, direct participation in political affairs is the best school for democracy.

It is of equal importance that a civic education teacher master instructional model, where $\mathrm{s} / \mathrm{he}$ has to display personality mastery by displaying self as an honest, noble, steady, stable, mature, sage, authoritative individual that can be a good example for students and the society. S/he will also demonstrate work ethics, high responsibility, self-pride in becoming a teacher, and self-confidence, and s/he will uphold the profession as a teacher.

Meanwhile, the social competences of civic education teachers will lead them to be inclusive, objective, and indiscriminative, regardless of students' sex, religion, race, physical condition, familial background, and economic status. They will also be able to communicate effectively, empathically and politely with fellow educators, education staff, parents, and the society, and able to adapt with any kind of workplace, anywhere in Indonesia with its social and cultural diversity.

Teachers along with the school personnel have to be role models for their students in the classroom and school, where students' totality as individuals is developed and guided, namely their cognitive, affective, and psychomotor abilities, both the substance and their learning skills. They are trained and provided opportunities to experience a number of desirable behaviours and attitudes. Hence, democratic behaviours in the classroom can be brought home and to other life environments as the formal culture, indirectly positioning the school as an agent of change for virtues in the environment.

Having civic educational professional attitude and traits or having mature civic education pedagogics in educating will result in an instructional atmosphere with a strong sense of civic education. Mastery of teacher competence, both the general and the specific, is very important and strategic. This is so because teachers play important roles compared to other components of education in creating classroom as democratic laboratory.

One study of schools in Brazil noted that,

There was little oral interaction between teacher and students over instructional issues. The dominant type of schoolwork was solitary work in textbooks, workbooks, notebooks and worksheets. Children are required to do fill-in types of exercises that called for short answers to factual questions. This typically followed a short and verbally economical introduction by the teacher of some new topic.... verbal interaction between teachers and students was limited to procedural issues, control and to economical question-and-answer sequences. There is little feedback [20].

In Africa schools have been characterized by hierarchical organization, rote learning, teacher-centered classrooms and the use of physical punishment,

Throughout Africa ... lessons involved frequent oral recitation of vocabulary or arithmetic exercises, delivered in unison by all pupils. This mechanical process, set by the curricula or teacher guide, helps control and engage the fifty to ninety restless pupils that commonly sit before the teacher. Thus curricular content helps signal and legitimate certain forms of authority and human interaction which come to be seen as normal in a modern (hierarchical) organization [21].

[1] stated that this is certainly not the case in contemporary South Africa where there is widespread concern not only about equity, as we have seen, but also about the education of democratic citizens. For example, an educational policy favored by the World Bank for some time, decentralization of educational decision-making, has also been a key part of government policy throughout the 1990s. However, while decentralization may well be a more efficient way of managing schools, in itself it is in the end merely a mechanism. The question is, efficient at what? Which educational goals is it helping to achieve? In 1991, with the approach of the first democratically elected government in South Africa, the National Party government in the all-white House of Assembly significantly decentralized power by creating what it termed 'model c' schools in which staff and parents would have more control over running the school. It was widely felt that this decentralization of power was aimed at giving all-white schools some measure of independence to protect their resources and admissions policies from future government control. The new government, however, has in a sense made all schools in the public sector into model $\mathrm{c}$ schools in that now all schools will have governing bodies that will have significant control over, for example, the aims of the school, language policy, school times, staffing, budgets, the collection of school fees, the purchase of teaching resources and the use of school facilities. Unlike the previous government, however, the purpose of this reform is to develop an accountable and democratically governed school system which will contribute to the development of democratic values and practices in the wider society: A school governance structure should involve all stakeholder groups in active and 
responsible roles, encourage tolerance, rational discussion and collective decision making [22].

\section{The Influence of School Environmental Factor on the Implementation of Civic Education Classroom as Democratic Laboratory}

Other factor that affects implementation of civic education classroom as democratic laboratory is school environmental factor. We found that there was a correlation of 0.702 with a significance level of $49.28 \%$. It can be translated as the factor of school environmental factor having a significant influence on the implementation of civic education classroom as democratic laboratory.

The school environmental factor required for the implementation of civic education as democratic laboratory is a classroom that can be functioned as a society miniature, which means a place for instruction through practicum method able to produce learning experience, where students interact with other students, educator, learning materials, and the environment to discuss and solve observable or directly experienced problems and prove by themselves what they have learned. This means that classroom as democratic library plays a significant role in improving the quality and instructional system of civic education. Thus, students do not only learn formally in the classroom but also outside the classroom. As a result, they will be habituated to cultivate democratic values that can change their behaviours.

Civic education as democratic learning demands and trains students to develop their social ability and independence as democratic citizens through cooperative learning and selfregulated learning. Through cooperative learning, students are trained to simultaneously develop their competences as citizens who are able to appreciate and respect differences around them; they will also be able to cooperate well with their peers and teacher, even with members of other schools; and what is equally important is they will have a strong commitment to reach shared goals. Additionally, through selfregulated learning students will develop to become independent citizens who believe in their own abilities and are free to be creative and work accordingly.

Furthermore, through habituation, students will get used to do positive things as good and intelligent citizens, such as to express opinion, negate teacher's and peers' opinion, answer teacher's and friends' question, respect peers' and teacher's opinion, express positive ideas, act honestly and with self-discipline, and be responsible for what they deliver. Hence, to allow for this habituation school management needs to make policies that civic education subject is not only part of the curriculum conducted through two-hour lesson per week, but more importantly, it is made into school program, such as religious month, honesty month, responsibility month, selfdiscipline month, tolerance month, solidarity month, caring month, independence month, and hard work or creative month.

"School impact" includes a number of formal or deliberate factors in politic education, such as a number of lessons (or the number of meetings for the lesson) and subjects taught on how to gain information and analyse various available alternatives. "School impact" also covers various actions/attempts in the school climate.

Students experiencing democratic leadership are more efficient and successful in achieving the group's objectives. They are closer (united) as a group and able to express group's achievement using the pronoun "we" when talking about their activities. They are less apathetic than the group with authoritarian leadership and are more encouraged to express their personal opinion in various meetings. Democratic climate also stimulates objective critiques. As a whole, they will show a higher level of justice and will not consider personal interest compared to other groups.

\section{The Influence of Civic Education Teachers on} Democratic Intelligence of Young Citizens as Students

Influence of civic education teacher on democratic intelligence of young citizens as students was also investigated Based on statistical calculation of data analysis, the correlation between civic teacher competence and democratic intelligence of young citizens as students was 0.552, which was categorized as quite high with a significance level of $30.47 \%$. This result means that civic education teacher competence was significant in fostering democratic intelligence of young citizens as students.

[23] stated that, a democracy would seem to demand direct access to public relevant and credible sources of knowledge, even as those sources are recognized as shaped by their own democratic differences in values and judgments. It may well be that enhancing public access to this knowledge will also prove a boon for inspiring faculty and students to give greater thought to writing for this expanded audience, taking the time to explain themselves in a way that will reward their work with a greater impact than it has previously had a chance of achieving. This openness may well prove a source of insight into the intricate links between the public and scholarly forces that drive research within a public sphere like the schools.

Besides containing knowledge, civic education subject contains civic skills, which include intellectual and participatory skills in national and state life. One example of intellectual skills is the skill in responding to various political issues, while an example of participatory skills is the skill to exercise the rights and obligations in law, such as immediately reporting a crime to the police.

Another competence is civic disposition, which is in fact the most substantial and essential dimension in civic education subject. Civic disposition is viewed as "the estuary" of the development of the two previous competences. By considering civic education subject's vision, missions, and objectives, it is observable that the subject is characterized by an emphasis on disposition, character, attitude, and other affective potentials.

Thus, a citizen should first have good civic knowledge, ultimately in the fields of politics, law, and moral in the national and state life. Then, a citizen is expected to have intellectual and participatory skills in the national and state 
life. Eventually, the knowledge and skills will shape a character or mature disposition that becomes daily habit and attitude. The character, disposition, attitude, or habit that reflects a good citizen are, for instance, religiosity, tolerance, honesty, fairness, democracy, appreciation for difference, respect for law, respect for others' rights, high nationalism, social solidarity, and the like.

Regarding the characteristics of democratic education, Balme and Bennis [24] argue that it should promote the participation of students in the construction of the school's structure and vision, and allow students to regulate their own ways of learning and living, with adults acting as guides and consultants instead of directing student activities.

\section{E. The Influence of School Environmental Factor on Democratic Intelligence of Young Citizens as Students}

The effect of school environmental factor on democratic intelligence of young citizens as students was also examined. The research results showed that the influence of school environmental factor on democratic intelligence was $26.52 \%$, and the correlation value was 0.515 , which was categorized as moderate. This implies that school environmental factor influenced on democratic intelligence of young citizens as students.

Civic education classroom instruction and outside the classroom but within the school environment has to have democratic atmosphere. One of the examples is teacher's leadership style. Leadership style pertaining to democratic intelligence of young citizens had a significant influence because students thought that what they learned and gained in school, especially in the teaching and learning process, were made guidelines to think, act, and behave. Democratic leadership style, where a learner-centred relationship between teacher and students takes place, encourages students to be democratic because students are given freedom to express opinion, always trained to discuss and make a consensus for every decision.

In this way, students will get used to democratic life. School is a community, which is an integral part of a society. School, as stated in [25], is called "a unit of education", which is an entity of national education medium serving the function to embody education holistically in an attempt of achieving national education objectives. In this regard, education process in school should be embodied in and by unit of education in the form of instructional process developing and shaping student's characteristics in democratic learning environment.

A democratic learning environment needs to be embodied by an educational entity in an attempt of improving the quality of school-based education. To build a democratic learning environment, an internal social-educational synergy should be established, necessitating systematic and systemic efforts to make school as a medium for democratic citizen development through civic education.

In its implementation, democracy cannot be inherited from one generation to the next, but should be done through education and habituation process. Alexis de Tocqueville, a French statesman who moved to the US, stated, "The habits of the mind, as well as 'habits of the heart', the dispositions that inform the democratic ethos, are not inherited" [26]. In other words, a democrat does not necessarily give birth to a democratic child if the child does not learn about democracy. To be a democrat, a process of education and instruction is needed to embody the life of Indonesian state and nation that is intelligent, religious, just and civilized, united, democratic, and prosperous. The characteristic of internal-conceptual society is basically very coherent with the concept and value of civil society.

\section{F. Civic Education Classroom as Democratic Laboratory Had a Significant Influence on Democratic Intelligence of Students}

In this part, an influence of civic education classroom on democratic intelligence of students was examined. Based on research results, there was a significant influence of civic education classroom as democratic laboratory on democratic intelligence of students for as much as $46.64 \%$, and the correlation value was 0.683 , which was categorized as high. This means that civic education class as democratic laboratory was very significant for democratic intelligence of students as young citizens. The result was corroborated by [27]. He conducted research at Vocational Secondary School 1 Yogyakarta and found that the correlational product moment was $r_{\text {count }}(0.313)>t$-table $(0.207)$. This means that "there was a positive and significant correlation between Learning Achievements of Civic Education and Democratic Intelligence of the Eleventh Graders of State Vocational Secondary School 1 Yogyakarta". Based on $\mathrm{F}$ test, it was found that $F_{\text {count }}>F_{\text {table, }}$, which means that there was a linear correlation between Learning Achievements of Civic Education and Students' Democratic Attitude.

Each society member highly desires good citizens who can participate in the social and national life. The majority of civic education teachers have the perception that to foster democratic intelligence, appropriate instructional medium is required. In this regard, classroom, where instruction takes place, is able to facilitate the development of various potentials and competences of young citizens as students. Hence, teachers' role and function in managing the class are highly required, including how teachers create democratic education atmosphere that constantly considers egalitarian aspect (equality) between educators and students. Teaching does not have to be top-down, but should be balanced with bottom-up. There is no more coercion from teachers; rather, there will be bargaining between the two parties in determining learning objectives, materials, media, and evaluation. In structural and cultural communication between educators and students, a healthy, normal, and responsible interaction is created. Students may express their opinion, show their feelings, and act according to their belief, on the grounds that they can argue responsibly and scientifically. Students do not only understand democracy, but also practice to debate, respect others' view and self-esteem, and abide by rules applied in a discussion setting [28]. 
Analysing experts' opinion on civic education functioning as democratic laboratory, [26] asserted that civic education in facing the globalization era should develop civic competences that include: Civic knowledge, civic skills, and civic disposition. The three aspects are analogous to Bloom's concept on developing students' abilities, comprising of cognitive, psychomotor, and affective domains.

In order to foster democratic intelligence of young citizens through the implementation of classroom as democratic laboratory according to civic teachers' perceptions, in addition to needing appropriate infrastructure, requires a development of various instructional approaches, methods, and models. One of the approaches that can be used is research-based learning instructional model, where civic education instructional process is begun with simple research by students, where the results are made into theme or topic to be discussed in the classroom.

Students' democratic intelligence will be fostered by itself through habituation in the classroom developed by teachers. Hence, competent teachers are needed in conducting civic education instructional process that will use various instructional methods and models.

Based on quantitative research results, it was found that the most influential factor in fostering students' democratic intelligence was democratic laboratory, where the correlation coefficient value of civic education classroom as democratic library and democratic intelligence of young citizens was 0.683 (a moderate correlation). With this value, it was revealed that the influence of civic education classroom as democratic laboratory variable on democratic intelligence of young citizens was $46.60 \%$.

Students had the courage to be willing and able to express opinion, negate their friends' opinion, as well as giving opportunities for their peers to express their opinion. So, tolerance and mutual respect are inseparable from teachers' role in positioning themselves as facilitators in the classroom. Students are no longer asked to listen to lecture, but are trained to do activities optimally in the instructional process, so that interaction between students and their peers, between them and the teaching materials, and between them and the teacher will take place conductively in a fun learning atmosphere. This is the essence and meaning of civic education instruction in a democratic atmosphere.

Fostering democratic intelligence of citizens should be started from the small scale, namely in the civic education classroom instruction functioning as democratic laboratory. Hence, civic education teachers should be able to cultivate equality, responsibility, tolerance, and the like. The same is true for students; they have to uphold justice, because democracy without justice or the reverse will not run well. Equality, respect for differences, steadiness, dialogue, responsibility, participation and sustainability are the spirits of democratic instruction.

Fostering equality is a part of teacher competences stipulated in Oklahoma, where it is stated that one of the general competences teachers should master is equality, where they have to understand that students are disparate in terms of their approaches to instruction, and teachers should create instructional opportunities that can be used by each of the disparate students. This means that teachers should understand that all students learn differently. Teachers have to deliver lessons in appropriate ways and fulfil the needs of all students. Students bring all individual differences into the classroom as well as different ways of learning. Some of the differences are probably caused by late or accelerated development, innate disability, language differences, learning style or social factors. This is where teachers play their roles and functions to unite differences in equality.

The instructional model of "We the People ... Project Citizen" or "Portfolio-Based Civic Education Learning Practice" has been acknowledged and proved by the author to be able to foster democratic intelligence of young citizens or students. This is because through this instructional model, since the very beginning students have been trained and habituated to identify various problems pertaining to political policies, both in their school environment or neighbourhood, and their region. Based on the identification results, students identify and determine information sources to gain various kinds of information regarding the formulated problems.

\section{CONCLUSION}

Civic education teacher competence, classroom environment, and civic education classroom as democratic laboratory had significant influences on the effort of fostering democratic intelligence of young citizens as students. However, the cultivation of democratic values in the world of education requiring figures with intelligence, responsibility, and high appreciation for democratic values, especially through civic education subject, had not been successful. Civic education class no longer illustrates a miniature of society reflecting social and cultural realities due to civic education teachers not having the expected competences and classroom environment not encouraging democratic atmosphere. To solve these issues, teachers should create civic education classroom as democratic laboratory, namely a classroom able to train students to be courageous to inquire, express opinion, argue, tolerate, learn to appreciate and respect other's opinion; be responsible, honest and fair, and be responsive to various problems currently faced by the society and the nation. The implementation of civic education classroom as democratic laboratory creates a figure of young citizen who has intelligence, responsibility, and high appreciation for democratic values. This is so because in such a classroom young citizens are invited to learn, analyse, and assess various problems in their surroundings.

\section{REFERENCES}

[1] Harber, C. 1997. International Developments ant the Rise of Education for Democarcy. Compare: A Journal of Comparative and International Education. 27 (2). 179-191.

[2] Somantri, M. N. (2001). Menggagas Pembaharuan Pendidikan IPS: Bandung: Rosda. 
[3] Englund, T. (2000). Rethingking Democracy and Educatin: Towards and Education of Deliberative Citizens. Journal of Curriculum Studies. 32 (2). 305-313.

[4] MacMath, S. (2008). Implementing a Democratic Pedagogy in the Classroom: Putting Dewey into Practince. Canadian Jurnal for New Scholars in Educaion. 1 (1). 1-12.

[5] Rowe, $\mathrm{K}$ et.al. Living Democracy in the Classroom: Changing the Approach. Educational in a Democracy: A Journal pf the National Network for Edecational Renewal. 5. 104-125.

[6] Odhiambo, et al. (2014). The Crisis of Democratic Education: Building on African Indigenous Principles and Social Science Studies in Developing Sustainable Democratic Education in Kenya. Internatonal Journal of Education and Research. 2 (3). 1-10

[7] Vinterek, M. (2010). How to Live Democracy in the Classroom. Journal of Educational Inquiry. 1 (4). 267-380.

[8] Applebaum, B. (2003). Social Justice, Democratic Education and The Silencing of Words that Wound. Journal of Moral Education. 32 (2). 151 162

[9] Moswela, B. (2010). Democratic Educaton in the Classroom: An Education Law Perspective. Journal of Education Administration and Policy Studies. 2 (4). 56-62.

[10] Benjamin, A. et.al. (2010). Democratic Leraning in U.S. Career Education. Journal of Career an Technical Education. 25 (2). 120-132.

[11] Margison, E.J.H, \& Graham, B. (2001) Principles for Democratic Learning in Career Eucation. Canadian Journal of Education. 26 (3). 341361.

[12] Jotia, A.L. (2011). Educating for Democratic Engangement in Boswana Democracy: Chalengges of Promotinf Democraic Education. Journal of Social Development in Africa. 26 (1)

[13] Creswell, J.W. (1994). Research Design : Qualitative \& Quantitative Approaches. London: Sage Publications.

[14] Pramudia, J. R. (2006). Orientasi Baru Pendidikan: Perlunya Reorientas Posisi Pendidikan dan Peserta Didik. Jurnal Pendidikan Luar Sekolah. 3 (1). 29-38.

[15] Winataputra, Udin Saripudin. (2007). Civic Education: Konteks, Landasan, Bahan Ajar dan Kultur Kelas. Bandung: UPI Press.
[16] Sihono, T. (2011) Upaya Menuju Demokratisasi Pendidikan. Jurnal Ekonomi dan Pendidikan, 8 (1). 1-22

[17] Choi Choi, S. (2007). Democratic Leadership: The Lesson of Exemplary Models for Democratic Governance. International Journal of Leadership Studies. 2 (3). 243-262.

[18] Davies, I, et. al. 2005. Globalising Citizenship Education? A Critique of 'Global Education' and 'Citizenship Education'. British Journal of Educational Studies.53 (1). 66-89.

[19] Gray, P \& Chanoff, D. (1986). Democratic Schooling: What Happens to Young People Who Haeve Charge of Their Own Education. American Journal of Educaton. 94 (2). 182-213.

[20] Leonardos, A. 1993. 'CIEP': a democratic school model for educating economically disadvantaged students in Brazil?, in: H. LEVIN \& $\mathrm{M}$. LOCKHEED (Eds) Effective Schools in Developing Countries (London, The Falmer Press).

[21] Fuller, B. 1991. Growing Up Modem (London, Routledge).

[22] Department of Education. 1996. Education White Paper 2: The Organisation, Governance and Funding of Schools. Pretoria.

[23] Willinsky, J. 2002. Democracy and Education: The Missing Link May Be Ours. Harvard Educational Review, 72(3), 367-392

[24] Korkmaz, H,E \& Gumuseli, A.I. (2013). Development of the Deocaratid Education Environment Scale. International Online Journal of Educational Science. Can access in www.iojes.net. 35-160

[25] The Law of the Republic of Indonesia No. 20 of 2003

[26] Branson, M.S, (1999). Belajar Civic Education dari Amerika. Yogyakarta: Kerjasama LKIS dan The Asia Foundation

[27] Prasetyo, G. E. (2012). Pengaruh Prestasi Belajar Pendidikan Kewarganegaraan terhadap Sikap Demokratis Siswa Kelas XI SMK Negeri 1 Yogyakarta. Jurnal Citizenship. I (2). 105-112

[28] Suharto, T. (2005). Konsep Dasar Pendidikan Berbasis Masyarakat Jurnal Cakrawala Pendidikan. XXIV (3). 323-346 